\title{
The effect of family and internal control on family firm performance: evidence from Indonesia Stock Exchange (IDX)
}

\author{
Danies Pradana Yudha \\ Arif Singapurwoko \\ Management Department \\ Universitas Islam Indonesia, Indonesia
}

\section{Keywords}

Family control, internal control, firm performance

\begin{abstract}
The majority of companies listed on IDX are family companies, which have several advantages and disadvantages that affect firm performance. The results of previous studies on the influence of family firms are still inconsistent.

This study aims at determining the effect of family control as measured by family ownership and family involvement on the corporate performance; and describing the influence of internal control as performed by independent commissioner and audit committee on the performance of family firms with the control variables are firm size and firm age. The population of this study was all family companies listed on the Indonesia Stock Exchange (IDX). Meanwhile, the sample used was purposive sampling. There were 76 companies from the entire family companies listed on the Indonesian Stock Exchange (IDX) from 2010 to 2014 which met the criteria so that the overall observed data were 380.

The analysis tool used was a multiple linear regression. The results show that partially, family ownership, independent commissioner and the control variables, firm size and age, have a positive and significant impact on the firm performance. On the other hand, respectively, family involvement and audit committee have a significantly negative and insignificantly negative impact on the performance of the company.
\end{abstract}

Corresponding author:Arif Singapurwoko

Email address for corresponding author:arif_singa@uii.ac.id

First submission received: 3rd February 2017

Revised submission received: 21st February 2017

Accepted: 21st March 2017

\section{Introduction}

The firm performance can be seen through its financial condition of the company which is analyzed by the tools of financial analysis, in order to determine whether the performance is good or bad. The result reflects the performance in a particular period. Memom and Tahir (2012) explain that performance is a quality of any company that has satisfactory result. Therefore, in order to obtain optimal business performance, a good control between management function including the functions of ownership and management is needed. Ownership structure characteristics of the companies in Indonesia have been dominated by family, in both family company founder and non-founder. According to the survey about family business in Indonesia conducted by an expertise from accounting firm, Pricewater house Coopers (PwC) in 2014, there are $87 \%$ of companies in Indonesia having family involvement portrayed as owner and management. The competition between family and non-family can be viewed from two perspectives: the ownership where family members control the firm's assets substantially and the involvement of family members in management. A concentrated ownership structure raises the potential of controlling shareholders to become deeply involved in the management as well as the power and incentive to enable negotiation and encourage 
the company's contract with the stakeholders (Dyanty et al., 2012). This may reduce the agency problem which is a conflict between management and shareholders. The structure of concentrated ownership also provides huge amount of incentives for supervising, monitoring, and controlling the activities of managerial firms, where one of the actions is choosing people of his own family members to manage the company (Giovannini, 2010).Family involvement in management is assumed to reduce information asymmetry and conflict of interest within the company. Patriarchy and nepotism have a very close relationship in a firm that has a large family control making the practices marked as a common/special characteristic of a family company. According to the 6-D Model assessment in Indonesia, individualism dimension obtains the lowest value meaning, and thus the society tends to be collectivist (Hofstede, 2003).Further research is needed to investigate if both practices affect the performance of family firms. Measuring the company's performance can also be determined by investigating how extentlythe principles of good corporate governance (GCG) are applied. Therefore, inability to manage the company which is in accordance with the principles of good corporate governance is synonymous with a weak performance. The existence of inspectors as an internal control formed by the board of directors is expected to minimize the acts of the unprofessional family director. One of the internal control efforts in GCG mechanism is the presence of independent commissioner. Agency theory states that independent commissioner is an important factor in establishing the independence of the board. Independent commissioner is expected to act in a neutral manner so as to create balancing interests of minority shareholders and other parties concerned.

\section{Literature Review}

\subsection{The Influence of Family Control on Firm Performance}

Ownership by family unsurprisingly has both positive and negatives to the company. The existence of family company founder is converted into superiority for supervising the business. The family has great opportunity to oversee professional managers in an effort to maintain the firm performance. Empirically, the positive impact of family companywasrecorded by Villalonga and Amit (2006).The unique characteristic of family firm is the relationship between children and parents. This can help align the strategy of choice for the growth of companies. Families tend to be more interested in projects that can enhance company's value. On the nature relationship of household, the family concerns to other parties on his behalf. In such case, family manager will be committed to run the organization properly. According to Sanjaya (2013), self-actualization factor within the family is one of the reasons family managers committed to run the company properly. Lee (2006) and Anderson and Reeb (2003) through their studies stated that family involvement in the management has a positive effect on the firm performance. Based on the previous explanation, the research hypotheses are:

H1: Family ownership has a positive effect on the firm performance.

$\mathrm{H} 2$ : Family involvement has a positive effect on the firm performance.

\subsection{The Effect of Audit Committee on Firm Performance}

Audit committee holds the responsibility of the firm financial report. One of the foremost functions of the audit committee is to review the financial data of the company on continuous basis and strengthen internal accounting controls, in order to enhance reliability and integrity of financial reporting. A good management system of a company requires a thorough co-ordination among the three constituents of audit: the board, the internal auditors, and the external auditors (Hundal, 2013).The audit committee not only participates in the process in which management disseminate information to the auditors and release unbiased information to reduce information asymmetry between insiders and outsiders, but also plays an important role in ensuring that statutory auditors are not in the influence of management. Therefore, audit committee can be used as a mechanism to reduce agency problems faced by the firms (Jensen and Meckling, 1976).Zaire (2014) explained that 
audit committee has a positive effect on the firm's financial performance. Based on the statement above, the third hypothesis of this study is:

H3: Audit committee has a positive effect on the firm performance.

\subsection{The Effect of Independent Commissioner on Firm Performance}

Agency theory indicates as that conflict of interests between agents and principal can be reduced with proper supervision. The existence of independent board of directors will improve the quality of supervision functioning within the company. Greater the proportion of independent commissioner indicates that the supervisory function would be better. Executive directors act as mediators in disputes among the managers and also oversee internal management policy as well as providing advices to management. Independent commissioner is the best position to carry out the monitoring functions for the creation of good corporate governance in the company. Independent commissioner is a member of the board who does not have the financial, managerial, share ownership and/or family relationship with the other commissioners, directors, and/or shareholders' controller or other relationships which could affect their ability to act independently. Pathan et al. (2007) and Abor and Biekpe (2007) conclude that there is a positively significant effect between the proportion of independent commissioners with the firm performance, especially profitability. Based on this description, the fourth hypothesis of this study is:

H4:Independent commissioner has a positive effect on firm performance.

\section{Research Model}
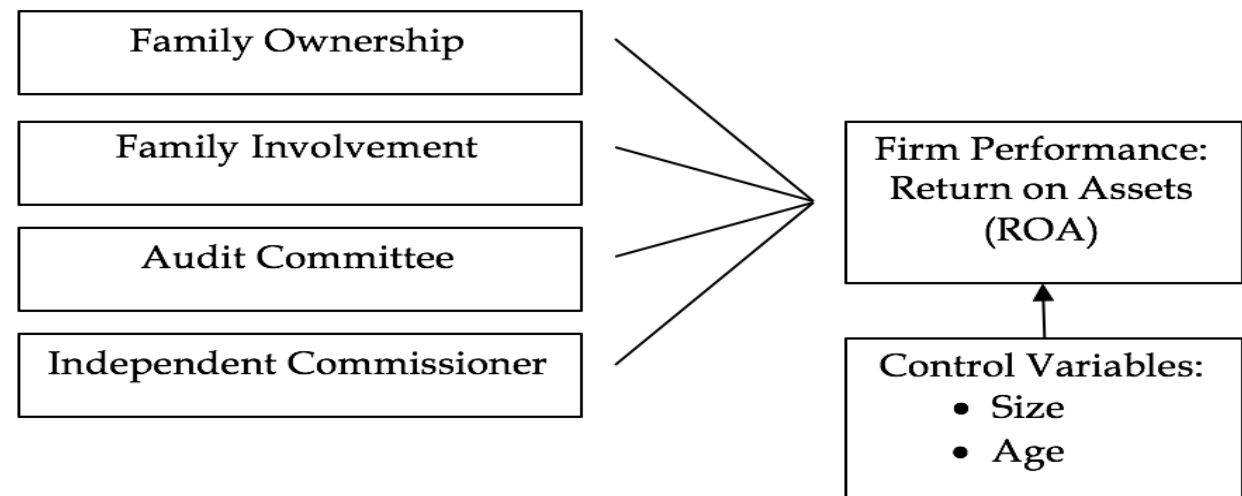

4. Methodology and Variables

Figure 1. Research Model

\subsection{Sample selection and data collection}

The population of this study was taken from all companies listed on the Indonesian Stock Exchange (IDX).Purposive sampling was adopted to conduct this research. The samples were limited to the following criteria: Family firms listed on the Indonesia Stock Exchange (IDX) in the period of 2010 to 2014.

1. Family firms that have an ownership with a minimum of share are $5 \%$ by families or groups (institutions) in the period of 2010 to 2014.

2. Family firms that have family involvement on the board of directors for the period of 2010 to 2014.

3. Independent commissioners and audit committees which were recorded in the family firms during the period of 2010 to 2014. 
Table 1

Tools of Measuring Variables

\begin{tabular}{|c|c|}
\hline Variables & Measuring Tools \\
\hline \multicolumn{2}{|l|}{ Dependent Variable } \\
\hline Firm Performance (ROA) & Ratio of Annual Net Income to Average Total Assets \\
\hline \multicolumn{2}{|l|}{ Independent Variables } \\
\hline Family Ownership (FO) & $\begin{array}{l}\text { Percentage of total shares (minimum owned 5\% of firm's } \\
\text { equity) from: } \\
\text { a. shares directly owned by family members; } \\
\text { b. cross-shareholders from company owners group } \\
\text { or indirect ownership of the family structure; and } \\
\text { c. ownership by the agency controlled by the family. }\end{array}$ \\
\hline Family Involvement (FI) & Ratio of Family CEOs to Total CEOs \\
\hline Audit Committee (AC) & Total Audit Committees \\
\hline Independent Commissioner (IC) & $\begin{array}{l}\text { Ratio Total Independent Commissioners to Total Board of } \\
\text { Commissioners }\end{array}$ \\
\hline \multicolumn{2}{|l|}{ Control Variables } \\
\hline Firm Size (SIZE) & Natural Logarithm of Total Assets \\
\hline Firm Age (AGE) & $\begin{array}{l}\text { The difference in observation year with founding year of } \\
\text { the company. }\end{array}$ \\
\hline
\end{tabular}

\subsection{Model Specification}

To answer the research hypothesis, this study used regression analysis tools from SPSS as follows:

$$
R O A=\alpha+\beta 1 F O+\beta 2 F I+\beta 3 A C+\beta 4 I C+\beta 5 S I Z E+\beta 6 A G E+\varepsilon
$$

Where: ROA is the firm performance, $\alpha$ is a constant, FO is family ownership, FI family involvement, AC is audit committee, IC is independent commissioner, SIZE is the firm size, AGE is the firm age, and the $\varepsilon$ is the error term.

\section{Findings and Discussion}

The analysis was started by the descriptive statistics, followed by the correlation analysis, and then the results of the regression analysis were shown and discussed to see whether the hypotheses are validated or not. The analysis was done using SPSS program.

\subsection{Descriptive Analysis}

Descriptive statistics of research variables are summarized in Table 2.The average variables show that family ownership amounted to $51.70 \%$, family involvement amounted to $33.10 \%$, audit committee amounted to 2.56 rounded to 3, independent commissioner amounted to $37.66 \%$, size amounted to 28.4749, age of 32.5395 and ROA amounted to 4.6295.This might imply that the effect of family ownership, family involvement, audit committee and independent commissioner in family firms in Indonesia was quite large, while the control variables of size and age show the average of size and age of the sample companies. 
Table 2

Descriptive Statistics

\begin{tabular}{lrrrr}
\hline \multicolumn{1}{c}{ Variable } & \multicolumn{1}{c}{ Minimum } & \multicolumn{1}{c}{ Maximum } & \multicolumn{1}{c}{ Mean } & \multicolumn{1}{c}{ Std. Deviation } \\
\hline Family Ownership & .05 & .98 & .5170 & .23907 \\
Family Involvement & .00 & 1.00 & .3310 & .20760 \\
Audit Committee & .00 & 4.00 & 2.5632 & 1.05456 \\
Independent Commissioner & .00 & .80 & .3766 & .14073 \\
Size & 24.00 & 33.95 & 28.4749 & 1.77848 \\
Age & 1.00 & 73.00 & 32.5395 & 10.86550 \\
ROA & -19.10 & 32.20 & 4.6295 & 6.04103 \\
\hline
\end{tabular}

\subsection{Hypothesis Test}

\subsubsection{Coefficient of Determination Regression (Adjusted $\mathbf{R}^{2}$ )}

According to Table 3, it can be seen that the coefficient of multiple determination (Adjusted $\mathrm{R}^{2}$ ) is 0.058 . The result can be interpreted that $5.8 \%$ of family firms' performance listed in Indonesia Stock Exchange 2010-2014 period has been influenced by the four independent variables consisting of variable family ownership, family involvement, audit committee and independent commissioner as well as control variables, namely firm size and firm age. Meanwhile, the remaining of $94.2 \%$ has been influenced by other variables which are not included in the research model.

Table 3

Coefficient of Determination

\begin{tabular}{ccccc}
\hline $\mathrm{R}$ & R Square & Adjusted R Square & Std. Error of the Estimate & Durbin-Watson \\
\hline $.270^{\mathrm{a}}$ & .073 & 0.058 & 5.86253 & 1.808 \\
\hline
\end{tabular}

Notes:

The predictors are Intercept, Family Ownership, Family Involvement, Audit Committee, Independent Commissioner, Size and Age. The dependent variable is ROA.

\subsubsection{T-Test}

Based on Table 4, the multiple regression model for corporate performance (ROA) over the affective factors which consist of family ownership, family involvement, independent commissioner and audit committee as well as control variables, namely firm size and firm age is as follows:

$$
R O A=-90.992+18.164 F O-5.584 F I-0.065 A C+14.581 I C+2.660 S I Z E+0.216 A G E
$$

Table 4

T-Test

\begin{tabular}{lrrrrr}
\hline \multirow{2}{*}{ Model } & \multicolumn{2}{c}{ Unstandardized } & \multicolumn{2}{c}{$\begin{array}{c}\text { Standardized } \\
\text { Coefficients }\end{array}$} & \multicolumn{2}{c}{ Coefficients } & \multirow{2}{*}{ Sig. } \\
\cline { 2 - 5 } & \multicolumn{1}{c}{$\mathrm{B}$} & \multicolumn{1}{c}{ Std. Error } & \multicolumn{1}{c}{ Beta } & & \\
\hline Intercept & -90.992 & 10.982 & & -8.286 & $.000^{* *}$ \\
Family Ownership & 18.164 & 2.240 & .719 & 8.109 & $.000^{* *}$ \\
Family Involvement & -5.584 & 1.249 & -.192 & -4.472 & $.000^{* *}$ \\
Audit Committee & -.065 & .053 & .011 & -1.221 & $.223^{* *}$ \\
Independent Commissioner & 14.581 & 1.454 & -.340 & 10.031 & $.000^{* *}$ \\
Size & 2.660 & .391 & .783 & 6.801 & $.000^{* *}$ \\
Age & .216 & .037 & -.388 & 5.771 & $.000^{* *}$ \\
\hline
\end{tabular}

Notes:

Significant at $5 \%\left(^{*}\right)$. The dependent variable is ROA 
The above multiple regression equations portray family ownership and independent commissioner as well as the control variables, namely size and age, having a positive direction regression coefficient on corporate performance (ROA).This indicates that the variable of family ownership, independent commissioner and the control variables, namely have positive impact on ROA. Meanwhile, family involvement and audit committee variable have negative regression coefficient direction of the firm performance. This suggests that family involvement and audit committee will give a negative impact on firm performance (ROA).The results of T-test using SPSS program are as follows:

\section{Hypothesis 1}

Based on T-test results on family ownership variable shown in Table 4 above, it is found that the value of regression coefficient is 18.164 with a p-value amounted to 0.000.Since the p-value is less than the significance level $(\alpha=5 \%)$, the first hypothesis, which states that the family ownership positively affects financial performance, is acceptable. In relevance to this study, Demsetz and Lehn (1985) say that the company whose ownership is concentrated on the family has a tendency to perform oversight to the company. This is because most of the property owned by the family has been invested in these companies. Therefore, they tend to be very concerned about the future of the company and have desired motivation to constantly monitor the firm performance. Moreover, the results of the research is affected by the involvement of family ownership which yield company governance and good financial management because the shareholder structure coming from a family can reduce agency problems.

\section{Hypothesis 2}

Based on T-test results on family involvement variable shown in Table 4, it is found that the value of regression coefficient is -5.584 with a p-value amounted to 0.000 .Since the regression coefficient is negative and the p-value is less than the significance level ( $\alpha=5 \%$ ), the second hypothesis, which states that family involvement has a positive effect on financial performance, is rejected. The results of this study has been irrelevant to the previous study conducted by Anderson and Reeb (2003) which states that a director who comes from family members can provide better performance than external directors. From this study, it can be inferred that the reason for such a phenomenon is their great control in the family company which causes great emotional attachment to family as this will reduce the company's focus on its purpose. In addition, great controls also make owners dominate the current decision-making process, thus it causes the expropriation of the minority shareholder which will make the company bear unnecessary cost that can reduce the firm's profitability. Meanwhile, this expropriation is also responded negatively by investors, thus the company's value has decreased. This finding supports the study conducted by Prabowo and Simpson (2011).

\section{Hypothesis 3}

Based on T-test results on audit committee variable shown in Table 4, it is found that the value of regression coefficient is -0.065 with a p-value amounted to 0.223 .Since the regression coefficient is negative and the $p$-value is greater than the significance level $(\alpha=5 \%)$, the third hypothesis, which states that audit committee has a positive influence on the financial performance, is rejected. The result has been irrelevant to the research of Ziaee (2014) which states that audit committee has a positive and significant impact on financial performance of companies in Iran. The audit committee is seen to be one of an important mechanism for reducing agency costs by oversight of financial reporting, financial disclosure, regulatory compliance, and risk management activities. The non-significant result for audit committee may be due to the fact that most firms only have three members of audit committee that solely meet the minimum number required on the board. Further, most audit committees are not only serve in one firm, but also in several firms, hence they are unable to perform their duties and functions effectively. 


\section{Hypothesis 4}

Based on T-test results on independent commissioner variable shown in Table 4, it is found that the value of regression coefficient is14.581 with the value of $p$-value is 0.000 .Since the $p$-value is less than the significance level $(\alpha=5 \%)$, the fourth hypothesis, which states that independent commissioner has a positive effect on financial performance, is acceptable. The study of this variable is in line with the studies of Pathan et al. (2007), and Abor and Biekpe (2007).Non-executive director can act as a mediator in disputes between managers and oversee internal management policy as well as provide advice to management. The greater the number of independent commissioner is, the more likely decisions made refer to the company's interest.

\section{The control variable: size}

Based on T-test results on the control variable firm size shown in Table 4, it is found that the value of regression is 2.660 with the value of $p$-value is 0.000 .Since the p-value is less than the significance level $(\alpha=5 \%)$, it can be concluded that firm size positively affects financial performance. From this study, it can be inferred that the reason of this phenomenon is big total value of the assets which shows the company's achieving maturity. In this phase, company's cash flow has been positive and achieves good prospector a relatively stable period. In addition, this condition indicates the capability of the company to generate better profits than companies with small total assets. The finding shows that the comparison between large firms and small firms are:(1) large firms are generally more diversified and have cash flows that tend to be stable, and (2) the possibility of bankruptcy faced by large enterprises will be smaller than small firms.

\section{The control variable: age}

Based on T-test results on the control variable firm age shown in Table 4 above, it is found that the value of regression coefficient is 0.216 with $p$-value is 0.000 .Since the $p$-value is less than the significance level $(\alpha=5 \%)$, it can be concluded that firm age positively affects financial performance. The probable reason is that financial performance of the long-founded companies can be defined as a good mark because they can preserve their existence in the market. From the age of firm establishment, firm age also demonstrates the firm's experience. The longer the age of the company is, the more experience and maturity they have.

\section{Conclusion and Recommendation}

The tested hypothesis result shows that three independent variables namely family ownership, family involvement, and independent commissioner have influence on the firm, while audit committee variable does not have any influence. However, only family ownership and independent commissioner show positive influence on ROA as the firm's performance standards. The involvement of family in firm management such as president director and board of directors brings negative influence in the firm's performance. It is suggested that further research will employ dummy on variables of family ownership and family involvement. Major and minor family ownerships which influence the firm are necessarily separated. Furthermore, dummy variable aims to separate or classify family involvement in the firm management, for instance a president director occupied by family or non-family.

\section{Research Limitations}

a. Researchers only used the data within the time span of 5 years. Measurement of family control has been portrayed by family ownership, family involvement, and a few control variables.

b. The researchers have limitation in taking the research variables. Dividend policy of the company depends not only on the factors examined, but also on the several other factors. It reflects that the coefficient of multiple determinants (Adjusted $\mathrm{R}^{2}$ ) only amounted to $5.8 \%$. The rest, $94.2 \%$, is influenced by other variables which are not included in the research model caused by several other factors. 


\section{References}

Abor, J. and Biekpe, N., 2007. Corporate governance, ownership structure and performance of SMEs in Ghana: implications for financing opportunities. Corporate Governance: the international journal of business in society, 7(3), pp.288-300.

Anderson, R.C. and Reeb, D.M., 2003. Founding-family ownership and firm performance: evidence from the S\&P 500.The journal of finance,58(3), pp.1301-1328.

Demsetz, H. and Lehn, K., 1985. The structure of corporate ownership: Causes and consequences. Journal of political economy, 93(6), pp.1155-1177.

Dyanty, V., Utama, S., Rossieta, H. and Veronica, S., 2012. The effect of controlling ownership to the related party transaction. Paper of National Accounting Symposium SNA XV.

Farida, Y.N., Prasetyo, Y. and Herwiyanti, E., 2010. The influence of corporate governance implementations towards earnings management of banking industries listed in Indonesia Stock Exchange over the period 2005-2007.Journal of Business and Accounting,12(2), pp.69-80.

Giovannini, R., 2010. Corporate governance, family ownership and performance. Journal of Management and Governance, 14(2), pp. 145-166.

Hofstede, G., 2003. Culture's Consequences: Comparing Values, Behaviors, Institutions, and Organizations Across Nations. Sage Publications.

Hundal, S., 2013. Independence, Expertise and Experience of Audit Committees: Some Aspects of Indian Corporate Sector. American International Journal of Social Science, 2 (5).

Jaggi, B. and Gul, F.A., 1999. An analysis of joint effects of investment opportunity set, free cash flows and size on corporate debt policy. Review of Quantitative Finance and Accounting,12(4), pp.371-381.

Lee, J., 2006. Family firm performance: Further evidence. Family business review,19(2), pp.103-114.

Memom, M.A. and Tahir, T.M., 2012. Performance analysis of manufacturing companies in Pakistan. Business Management Dynamics,1(7), pp.12-21.

Martínez, J.I., Stöhr, B.S. and Quiroga, B.F., 2007. Family ownership and firm performance: Evidence from public companies in Chile. Family Business Review, 20(2), pp.83-94.

Pathan, S., Skully, M. and Wickramanayake, J., 2007. Board size, independence and performance: an analysis of Thai banks. Asia-Pacific Financial Markets,14(3), pp.211-227.

Prabowo, M. and J. Simpson, 2011. Independent directors and firm performance in family controlled firms: evidence from Indonesia. Asian-Pacific Economic Literature, 25(1), pp.121-132.

Sanjaya, I.P.S., 2013. Family as The Ultimate Ownership Affects to Firm Performance. Sustainable Competitive Advantage (SCA),2(1).

Shleifer, A. and Vishny, R.W., 1986. Large shareholders and corporate control.The Journal of Political Economy, pp.461-488.

Villalonga, B. and Amit, R., 2006. How do family ownership, control and management affect firm value?.Journal of financial Economics,80(2), pp.385-417.

Ziaee, M., 2014. The effect of audit quality on the performance of listed companies in Tehran Stock Exchange. International Letters of Social and Humanistic Sciences, (21), pp.36-43. 